\title{
PEMANFAATAN KARBON AKTIF BIJI KELOR (Moringa oleifera) SEBAGAI PENYERAP LOGAM TIMBAL DALAM OLI BEKAS
}

\author{
Utilization of Activated Carbon from Moringa Seeds as an as an Adsorben of Lead \\ from Used Lubricant \\ Hajrah $^{1^{\star}}$, Ruslan$^{1}$, Prismawiryanti $^{1}$ \\ 1) Jurusan Kimia, Fakultas MIPA, Universitas Tadulako, Palu \\ Jl. Soekarno Hatta Km.9, Kampus Bumi Tadulako Tondo Palu, Telp. 0451- 422611 \\ *)Coresponding author: Hajrahichank@yahoo.com
}

Diterima 10 September 2018, Disetujui 18 November 2018

\begin{abstract}
The study about the utilization of activated carbon produced from moringa seed as an adsorbent of lead derivated from used lubricant has been done. The aim of the research was to determine the best condition for reducing the high amount of $\mathrm{Pb}$ (lead) derived from used lubricant. The moringa seed carbon was activated using $1 \mathrm{~N} \mathrm{HCl}$ as used as the adsorbent. Variations of adsorbent weight and contact time were used in this reasearch. The result showed that the highest reduction of lead concentration in $5 \mathrm{ml}$ of used lubricant was achieved by using 15 grams and 3 hours of adsorbent weight and contact time, respectively. It decreased the lead concentration as much as $86.31 \%$.
\end{abstract}

Keyword: adsorption, moringa seed activated carbon, lead concentration

\begin{abstract}
ABSTRAK
Telah dilakukan penelitian tentang pemanfaatan karbon aktif biji kelor sebagai penyerap logam timbal dalam oli bekas.Penelitian ini bertujuan untuk menentukan kondisi terbaik dalam penurunan konsentrasi timbal $(\mathrm{Pb})$ tertinggi yang terkandung dalam oli bekas. Adsorben yang digunakan adalah karbon biji kelor yang telah diaktivasi dengan asam klorida $(\mathrm{HCl}) 1 \mathrm{~N}$. Pada penelitian ini menggunakan 2 variasi yaitu variasi berat adsorben dan variasi waktu kontak adsorben terhadap oli bekas. Hasil penelitian menunjukkan bahwa penurunan konsentrasi timbal tertinggi pada $5 \mathrm{ml}$ oli bekas terdapat pada berat adsorben $15 \mathrm{gram}$, dan waktu kontak 3 jam. Konsentrasi timbal sebelum perlakuan adalah 2,5345 ppm dan konsentrasi sisa timbal yang didapatkan yaitu sebesar 0,3469 ppm dengan persentase penurunan konsentrasi timbal sebesar $86,31 \%$.
\end{abstract}

Kata kunci: Adsorpsi, Karbon Aktif Biji Kelor, Timbal 


\section{LATAR BELAKANG}

Seiring perkembangan zaman, maka teknologi yang digunakan manusia semakin berkembang. Hal ini dapat dilihat dengan meningkatnya jumlah kendaraan dari tahun ke tahun. Produksi otomatif sangat membantu aktivitas manusia, namun dilain sisi menimbulkan efek negatif bagi lingkungan salah satunya adalah berupa akumulasi oli pelumas mesin sebagai bentuk limbah cair.

Hingga saat ini di Indonesia masih terdapat pemakaian bahan bakar kendaraan bermotor dengan kandungan timbal yang cukup tinggi. Nilai ambang batas maksimum logam timbal pada bahan bakar kendaraan sesuai spesifikasi Ditjen Migas adalah 0,45 g/L (Santi, 2001), sedangkan berdasarkan ukuran internasional, kandungan maksimum timbal dalam bahan bakar kendaraan adalah 0,15 g/L. PP No. No. 18/1999 Pasal 1 Ayat (2) menguraikan bahwa bahan yang mengadung bahan berbahaya dan beracun (B3) dapat merusak lingkungan dan membahayakan makhluk hidup. Limbah B3 merupakan dampak negative dari kemajuan teknologi dan industri (Peraturan Pemerintah Republik Indonesia, 1999).

Penggunaan adsorben dapat dimanfaatkan untuk mengurangi bahan berbahaya seperti logam berat dalam pelumas bekas. Adapun beberapa penelitian yang menggunakan adsorben dalam menyerap timbal, seperti Pratiwi (2013) menggunakan kaolin dalam menyerap timbal pada oli bekas dengan metode acid clay treatment yang menvariasikan berat adsorben dan waktu kontak. Konsentrasi timbal mengalami penurunan seiring bertambahnya jumlah adsorben yang digunakan dan lamanya waktu kontak, efisiensi penurunan konsentrasi timbal pada berat adsorben 2,5 gram, 5 gram, 10 gram diperoleh masing-masing 55,24 \%, 55,35\%, 55,43\% sedangkan pada variasi waktu efisiensi penurunan konsentrasi timbal pada waktu kontak 15 menit, 30 menit, dan 60 menit diperoleh masing-masing 55,12\%, $55,19 \%$, dan 55,40\%. Sementara itu, Lestari (2010) digunakan kulit batang jambu biji sebagai penyerap timbal dengan menvariasikan berat dan waktu kontak konsentrasi timbal dari 100 ppm menjadi 53,04 ppm setelah penambahan adsorben kulit batang jambu biji seberat 3 gram dengan waktu kontak 90 menit. Prasaji et al. (2013) mengkombinasikan berbagai adsorben pada penjernihan oli bekas dengan menggunakan metode penyerapan. Dalam penelitian tersebut adsorben yang digunakan yaitu fly ash batubara maksimal 30 gram tiap $100 \mathrm{ml}$ oli bekas pada penggunaan alkilbenzensulfonat untuk menghilangkan kontaminan oli bekas, seperti logam berat. Salah satu bahan yang dapat dimanfaatkan adalah karbon aktif dari biji kelor.

Pemanfaatan biji kelor (Moringa oleifera) dalam menurunkan kandungan logam telah digunakan oleh Mukaromah 
(2008) dan melaporkan bahwa keefektifan bioflokulan Moringa oleifera yaitu $28,01 \%$ pada waktu pengendapan 120 menit, sedangkan pada $\mathrm{pH} 2$ mampu menurunkan kadar logam hingga $30,63 \%$. Dari uraian di atas maka dilakukan penelitian terhadap oli bekas dengan menggunakan adsorben lain yang memanfaatkan karbon aktif biji kelor sebagai media penyerap timbal $(\mathrm{Pb})$ agar tidak berbahaya bagi lingkungan dan kesehatan.

\section{METODE PENELITIAN}

\section{Bahan dan Peralatan}

Bahan yang digunakan dalam penelitian ini adalah Biji Kelor (Moringa oleifera). Bahan kimia yang digunakan zat aktivator $\mathrm{HCl} 1 \mathrm{~N}, \mathrm{HCl} 6 \mathrm{~N}$, aquadest, aquabidest, oli bekas, $\mathrm{HNO}_{3}$ pekat, $\mathrm{HNO}_{3}$ $0,1 \mathrm{~N}$, kertas $\mathrm{pH}$ universal, larutan standar $\mathrm{Pb}$.

Peralatan yang digunakan selama penelitian ini antara lain Tanur, gelas kimia $1000 \mathrm{~mL}$, oven, erlenmeyer $250 \mathrm{~mL}$, gelas ukur, blender, ayakan 100 mesh, batang pengaduk, buret, neraca analitik, magnetik stirrer, hot plate, SSA, timer, pipet tetes, pipet ukur, cawan porselen, labu ukur $500 \mathrm{~mL}$, labu ukur $100 \mathrm{~mL}$, labu ukur $50 \mathrm{~mL}$, labu ukur $10 \mathrm{~mL}$ dan botol polipropilen.

\section{Prosedur Penelitian}

\section{Pembuatan Karbon Aktif (Mu'jziah, 2010)}

Biji buah kelor dipisahkan dari kulitnya dan dikeringkan dengan sinar matahari selama 2 hari.Setelah itu biji buah kelor dikarbonisasi di dalam tanur selama 2 jam dengan suhu pembakaran $600^{\circ} \mathrm{C}$. Arang yang dihasilkan digiling dengan menggunakan blender lalu diayak dengan ukuran 100 mesh.

\section{Pengolahan Oli Bekas dengan Karbon Aktif}

Diukur sebanyak $20 \mathrm{ml}$ oli bekas ditambahkan karbon aktif biji kelor masing-masing 5 gram, 10 gram, 15 gram ke dalam Gelas kimia 100 mL. Kemudian diaduk dengan menggunakan magnetik stirrer masing-masing selama 1 jam, 2 jam, dan 3 jam. Lalu disaring dengan kertas saring.

\section{Analisa Logam Timbal dengan cara Dekstruksi kering}

Analisis dilakukan sesuai dengan SNI 01-3741-2012 (Badan Standarisasi Nasional, 2012). Lima $\mathrm{mL}$ oli bekas dimasukkan ke dalam cawan porselen dan dipanaskan secara bertahap hingga sampel tidak berasap lagi, kemudian dilanjutkan pengabuan dalam tanur $(450 \pm 5)^{\circ} \mathrm{C}$. Abu di tetesi air dan $\mathrm{HNO}_{3}$ pekat kira-kira $0,5 \mathrm{~mL}$ sampai dengan 3 $\mathrm{mL}$, selanjutnya dikeringkan dan dipanaskan kembali dalam tanur pada suhu $(450 \pm 5)^{\circ} \mathrm{C}$ hingga abu menjadi putih. Abu berwarna putih dilarutkan dalam $5 \mathrm{~mL}$ $\mathrm{HCl} 6 \mathrm{~N}$, sambil dipanaskan sampai kering, kemudian dilarutkan dengan $30 \mathrm{~mL}$ $\mathrm{HNO}_{3} \quad 0,1 \mathrm{~N}$ dan dimasukkan ke dalam labu ukur $50 \mathrm{~mL}$ selanjutnya ditepatkan dengan aquabidest. Larutan blanko 
disiapkan dengan penambahan pereaksi dan perlakuan yang sama seperti contoh. Absorbansi larutan baku dan larutan sampel diukur menggunakan SSA pada panjang gelombang maksimal 283,3 nm.

\section{HASIL DAN PEMBAHASAN}

\section{Karbon Aktif Biji Kelor}

Proses aktivasi karbon aktif biji kelor dilakukan dengan menggunakan pelarut $\mathrm{HCl} 1 \mathrm{~N}$. Metode ini berfungsi untuk mendegradasi molekul organik selama proses karbonisasi, membatasi pembentukan tar, membantu dekomposisi senyawa organik, dehidrasi air yang terjebak dalam rongga-rongga karbon, membantu menghilangkan endapan hidrokarbon yang dihasilkan serta melindungi permukaan karbon.

Larutan $\mathrm{HCl} 1 \mathrm{~N}$ yang ditambahkan sebagai aktivator akan meresap kedalam karbon dan membuka permukaan yang mula-mula tertutup oleh komponen kimia yang lain. Mu'jziah (2010) melaporkan bahwa selain sebagai aktvator, asam bereaksi dengan zat pengotor yang bersifat basa dan membentuk garam. Larutan $\mathrm{HCl}$ dapat melarutkan tar, hidrokarbon dan pengotor-pengotor yang dihasilkan pada proses karbonisasi serta dapat mengembangkan struktur rongga yang ada pada karbon dan juga dapat menghilangkan kadar abu pada proses karbonasi, sebab dengan adanya abu yang terbentuk maka kemampuan adsorpsi akan menurun (Botha, 1992 dalam Pari, 2004). Ion $\mathrm{H}^{+}$dari $\mathrm{HCl}$ akan masuk dalam struktur karbon menggantika zat pengotor, sehingga karbon aktif memiliki gugus asam Bronsted atau gugus donor poroton.

Karbon hasil aktivasi dibebaskan dari ion $\mathrm{Cl}^{-}$melalui pencucian dengan aquades, sehingga karbon aktif akan mudah mengikat logam timbal. Filtrat hasil penyaringan diuji dengan menggunakan kertas indikator universal yaitu mengukur $\mathrm{pH}$ dari filtrat sampai netral yaitu $\mathrm{pH} 7$. Karbon aktif juga perlu dibebaskan dari air, karena air dalam pori arang dapat mengganggu interaksi ion timbal dengan situs aktif arang. Proses pengeringan ini menggunakan oven dengan suhu $110^{\circ} \mathrm{C}$ dimana pada suhu tersebut air dapat menguap dikarenakan titik didih dari air adalah $100^{\circ} \mathrm{C}$.

\section{Hasil Adsorbsi Timbal dalam Oli Bekas}

Hasil penilitian yang diperoleh menunjukkan bahwa konsentrasi logam timbal menurun pada dalam oli bekas seiring dengan lamanya waktu perendaman oleh karbon aktif (Gambar 2). Hal ini dikarenakan adanya proses adsorpsi ion logam yang dilakukan oleh karbon aktif. Proses adsorpsi timbal dalam oli bekas dengan karbon aktif biji kelor dapat berlangsung dalam dua proses, yaitu adsorpsi kimia (chemisorpsi) dan adsorpsi fisik (physisorpsi) (Lestari, 2010).

Secara penampakan fisik, warna dari oli bekas sebelum perlakuan terlihat hitam pekat dan kental, namun setelah penambahan karbon aktif biji kelor terjadi 
perubahan seiring bertambahnya jumlah adsorben dan lama waktu kontak menjadi berwarna coklat dan encer.

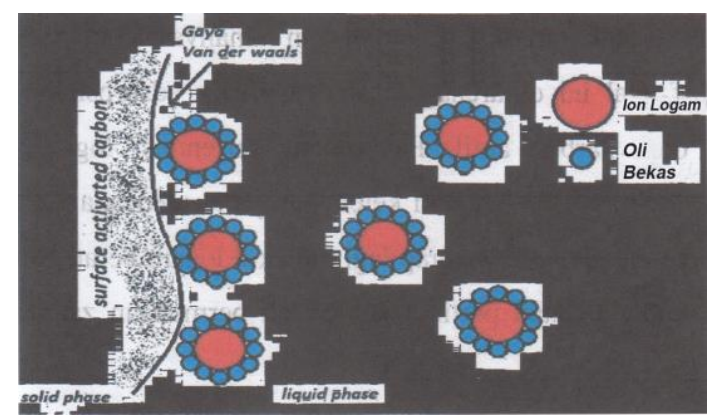

Gambar 1 Ikatan antara permukaan karbon aktif dengan ion logam (Oxtoby, 2001)

Proses adsorpsi pada karbon aktif terjadi karena adanya gaya Van der Waals (Gambar 1). Atom pada permukaan karbon aktif memiliki gaya yang tidak seimbang dibandingkan dengan susunan atom pada zat padat secara umum. Sehingga, molekul asing akan berusaha untuk memenuhi ketidakseimbangan ini bisa tertarik kepermukaan karbon aktif. Ion logam akan berdifusi menuju pori-pori karbon aktif karena adanya perbedaan konsentrasi adsorbat yang terdapat pada oli bekas dengan pori-pori karbon. Dimana ion yang terlarut dalam oli bekas akan terjadi ikatan ion dwi kutub, sehingga akan terbentuk menjadi satu kesatuan. Adsorbat (ion logam) membentuk sebuah lapisan tunggal (monolayer) pada permukaan adsorban (Manocha, 2001).

\section{Pengaruh Massa Adsorben dan Waktu Kontak terhadap Penyerapan Logam Timbal dalam Oli Bekas}

Berdasarkan hasil penelitian, konsentrasi timbal dalam oli bekas mengalami penurunan (Gambar 2). Dimana pada berat karbon aktif seberat 5 gram konsentrasi timbal dengan waktu kontak 1 jam, 2 jam dan 3 jam adalah masing-masing 1,515 ppm, 1,095 ppm, dan 0,971ppm.

Pada adsorben seberat 10 gram konsentrasi timbal dengan waktu kontak 1 jam, 2 jam dan 3 jam masing-masing adalah 0,721 ppm, 0,562 ppm, dan 0,483 ppm. Berikutnya pada adsoben seberat 15 gram konsentrasi timbal dengan waktu kontak 1 jam, 2 jam dan 3 jam adalah masing-masing 0,415 ppm, 0,381 ppm, dan 0,347 ppm.

Dari ketiga variasi berat adsorben 5 gram, 10 gram, 15 gram dan waktu kontak 1 jam, 2 jam, 3 jam tersebut diperoleh bahwa berat adsorben 15 gram dengan waktu kontak 3 jam menghasilkan persen penjerapan timbal tertinggi $86,31 \%$.

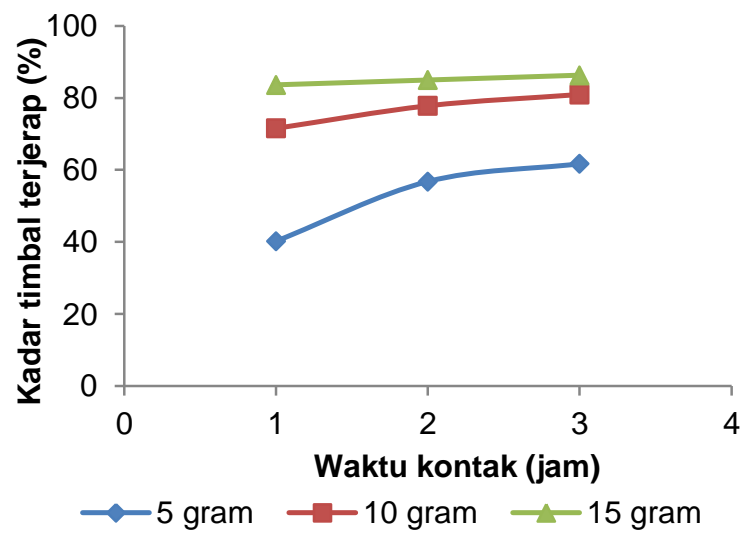

Gambar 2 Pengaruh waktu kontak terhadap jumlah logam timbal yang terjerap.

Berdasarkan uji sidik ragam, pada penambahan adsorben 5 gram, perubahan waktu kontak berpengaruh nyata terhadap konsentrasi timbal terjerap dan hasil uji lanjut Duncan menunjukkan 
setiap waktu kontak berbeda nyata. Demikian pula pada penambahan adsorben 10 gram. Pada penambahan adsorben 15 gram, kadar timbal terjerap pada waktu kontak 3 jam berbeda nyata dengan waktu kontak 1 dan 2 jam.

Kadar timbal yang menurun seiring dengan bertambahnya waktu kontak dikarenakan kontak antara adsorbat dengan adsorben menjadi lebih lama. Menurut Marti dan Okid (2001), gaya adsorpsi molekul dari suatu zat terlarut akan meningkat apabila waktu kontaknya dengan media semakin lama. Waktu kontak yang lebih lama memungkinkan proses difusi dan penempelen molekul adsorbat berlangsung lebih baik. Sementara itu, penambahan massa adsorben juga semakin menurunkan konsentrasi timbal dalam oli bekas dikarenakan luas permukaan adsorben akan lebih besar, sehingga mampu menjerap logam timbal lebih banyak (Stanley, 1997).

Dari hasil penelitian ini dapat dibandingkan dengan hasil penelitian sebelumnya oleh Pratiwi (2014) menggunakan metode Acid Aclay Treatment dengan menggunakan adsorben kaolin dari $150 \mathrm{~mL}$ minyak pelumas bekas terdapat pada konsentrasi adsorben 10 gram, waktu kontak 60 menit dengan efisiensi penurunan konsentrasi timbal $56,71 \%$, sedangkan pada penelitian ini, efisiensi penurunan konsentrasi timbal mencapai $71,55 \%$. Ini berarti bahwa adsorben karbon aktif biji kelor lebih efektif menyerap timbal dibanding adsorben kaolin.

\section{KESIMPULAN}

Berdasarkan hasil penelitian dapat disimpulkan bahwa penggunaan adsorben 15 gram dengan waktu kontak 3 jam mampu menjerap ion logam timbal dalam oli bekas dengan konsentrasi penjerapan tertinggi, yaitu $86,31 \%$.

\section{DAFTAR PUSTAKA}

Badan Standardisasi Nasional. 2012. SNI 01-3741-2012. Minyak Goreng. Jakarta: BSN.

Lestari, S. 2010. Pengaruh berat dan waktu kontak untuk adsorpsi Timbal (II) oleh adsorben dari kulit batang jambu biji (Psidium guajava $L$ ). Jurnal Kimia Mulawarman, 8(1).

Manocha, S., 2003. Porous Carbon. India. Sadhana. Vol.28, part 1\&2 P.348355

Marti. H, Okid P. A. 2001. Efektifitas Pengurangan Kadar Warna Limbah Cair Industri Batik dengan Ekstrak Khamir (Saccaromyces sp). Jurnal BioSMART, 3(2).

Mu'jziah S. 2010. Pembuatan dan Karakterisasi Karbon Aktif dari Biji Kelor Menggunakan Pengaktif $\mathrm{NaCl}$. [Skripsi]. Malang: Universitas Islam Negeri.

Mukaromah, L. 2008. Efektifitas Bioflokulan Biji Kelor dalam mengurangi kandungan Cr. [Skripsi]. Malang: Fakultas Sains dan Teknologi. Universitas Islam Negeri (UIN).

Oxtoby, D.W. 2001. Kimia Modern. Jakarta: Erlangga. 
Pari, G. 2004. Kajian Struktur Arang aktif dari Serbuk Gergaji Kayu Sebagai Adsorben Emisi Formaldehida Kayu Lapis. [Disertasi] Bogor: Program Studi Ilmu Pengetahuan Kehutana dan Sekolah Pascasarjana IPB.

Peraturan Pemerintah Republik Indonesia. 1999. PP RI No.18 Tahun 1999 tentang Pengelolaan Limbah Berbahaya dan Beracun (diunggah di http://sib3pop.menlhk.go.id/uploads/ Regulasi/PP181999.pdf pada tanggal 10 Maret 2018)

Prasaji, R., Dewita U. C., dan Santosa, H. 2013. Pemanfaatan Kombinasi Fly Ash Batubara, Alkilbenzenesulfonat, dan Zeolit pada Penjernihan Minyak Pelumas Bekas dengan Metode Penjerapan. JKTI. 2(4).
Pratiwi, Y. 2013. Pengelolaan Minyak Pelumas Bekas Menggunakan Metode Acid Clay Treatment. Teknik Sipil. Jurnal Teknik Sipil Universitas Tanjung Negara, 13(1).

Santi, D N. 2001. Pencemaran udara oleh timbal $\quad(\mathrm{Pb}) \quad$ Serta penanggulangannya. [Skripsi]. Fakultas Kedokteran Universitas Sumatera Utara. USU digital library

Stanley, G.G. 1997. The Extractive Metallurgy of Gold in South Africa. Vol. 1. Johannesberg: The South Africa Institute of Mining \& Metallurgy. 